\title{
The impact of strategic agility on employees' performance in commercial banks in Jordan
}

\section{Mohammad Izzat Al Halalmeh ${ }^{\mathbf{a}^{*}}$}

${ }^{a}$ Associated Professor in business Administration, Al Balaqa Applied University, Jordan

\section{H R O N I C L E}

\section{Article history:}

Received: November 18, 2020

Received in revised format:

November 282020

Accepted: December 27, 2020

Available online:

December 28, 2020

Keywords:

Strategic Agility

Employees performance

Commercial Banks

Jordan

\section{A B S T R A C T}

This study aimed to determine strategic agility impact on employees' performance in commercial banks in Jordan. A self-administrated questionnaire was developed according to research objective and hypotheses. The research population consisted of all managerial employees in Jordanian commercial banks. A random sample was selected consisting of 250 staff members who have senior administrative and supervisory positions in the commercial banks. Statistical techniques were used to test the research hypotheses. The research concluded a set of outcomes, the most important is strategic agility with its dimensions have an impact on employee performance in the commercial banks in Jordan. The research also concluded that strategic agility dimensions (strategic sensitivity, core capabilities, clarity of vision, strategic goals information technology selection, and share responsibility) influence on employee's performance in commercial banks in Jordan. The study recommended that commercial banks in Jordan have to adopt strategic agility approach to improve their employee's performance. The commercial banks must exert their best efforts to rapidly adapt to surrounding environmental variables. Commercial banks have to pay attention to human capital, which plays a major role in achieving good performance.

\section{Introduction}

Organization is considered as an open system that affects and affected by surrounding environment, which consists of a set of factors such as social, economic, legislative and political forces. Organization can effectively deal with this wide range of variables, so it must improve opportunities available in the external environment. It should have the needed knowledge to best use of these opportunities (Al-Sharif, 2015). Organizations face great challenges due to rapid environmental changes and technological developments as well. Therefore, traditional management methods are no longer useful, so they must move towards dealing with more modern and useful methods for the purpose of facing such changes. Among these methods is strategic agility in its dimensions including strategic sensitivity, collective commitment, and core capabilities, where organizations seek to face external changes and achieve the level of high performance. Strategic agility is one of the modern management methods that deal with unexpected changes, administrative and financial risks faced by companies, in order to increase their competitiveness, and to increase their market share and meeting customer needs and requirements (Ofoegbu \& Ayobmi, 2012, p154; Al-Tameemi \& Abd-Alghafur, 2020).

\section{Literature Review}

\subsection{Strategic Agility Concept}

The term strategic agility was applied by researchers at The Hague University for the first time in 1991 to build a flexible manufacturing system that contains the needed capabilities to meet rapidly changes in the market and respond to customer demands (Nematizeh \& khoshnood, 2017). Al-Maadidi (2016: 389) argues that strategic agility is the organizations ability that are looking to help in achieving rapid response to environmental changes by making strategic changes which would

* Corresponding author.

E-mail address: dr.alhalalmeh@bau.edu.jo (M. I. A. Halalmeh) 
enable organization to survive and continue. Strategic agility is the distinguished feature of new organizations. Some theoretical studies have presented various notions of strategic agility as a factor influencing the interpretation of how organizations perform their works speed and accuracy and outperform their competitors in their business environment (Al-Zaben, 2014). Strategic agility is defined as organization ability in achieving production cost reduction, increase market share and the number of customers, provide a new product or service in the best and fastest manner, and dismiss activities with no value as well as increase organization competitiveness (Dehaghi \& Navabakhsh, 2014, p315). Al-Abdi (2012, p. 154) indicates that agility makes the organization more responsive to market trends in addition to faster product and service delivery and at the lowest cost compared to non-agile organizations. Beltrame (2008) emphasizes that strategic agility is described as "the process of strategic orientation adaptation for organization with a response to changing environmental conditions, that is, focus on practicing change". He believes that an organization becomes agile when the firm is able to maximize the value of its core strengths continuously and whenever the greater agility, the greater the organization's options increased to provide what is necessary at the right time and limits appropriate for the customers. It is also defined as organization ability to respond quickly and easily to achieve response to changing unexpected situations, by having flexibility and speed that provide organization with the ability to change its work to take decisions in a timely manner, which requires various capabilities such as strategic sensitivity, collective commitment, bearing responsibility, flow and resources orientation that represent strategic agility core dimensions (Al-Badrani, 121, 2015). Liu $(2010$, p4) defines strategic agility as "the ability to continually adjust and adapt to a strategic orientation in the basic business, as a function of strategic ambitions and changing circumstances, it is not only an approach for producing new products and services, but also it is a way for creating new business models and innovative ways to create value for the company. Sajdak (2015) indicated that strategic agility is the required approach to external environment that involves surveying the sample and evaluating the potential impact of trends in a particular industry.

\subsection{The importance of strategic agility}

Strategic agility is the key to success in a dynamic and fast-changing business environment, in addition to taking advantage of opportunities in a turbulent market, it does not mean the absence of a strategy, but rather than strategic planning and emphasizes strategic thinking and clear vision, which is a common concept between strategy development and implementation (Santal,2009: 36). Nematizadeh and Khoshnood (2017: 223) explained that strategic agility dimensions are: clarity of vision, core capabilities, choice of strategic goals, shared responsibilities, and decision-making.

\subsection{Employee Performance concept}

Performance is "the number of results achieved by a person, team organization or process" (Chow \& Chew, 2013). Pawirosumarto et al. $(2017,608)$ defined performance as "the degree to which an individual can achieve the tasks and duties in which the associated job is based on the obtained. Results". Anita $(2014,8)$ defined performance as "the degree to which an individual can carry out his / her job responsibilities, including responsibilities and duties". In this regard employee's performance was defined as: "worker's performance as the degree of mastery of the worker for a specific activity that he can accomplish within the framework of his skills, abilities and the requirements of his job" (Guan \& Frenkel, 2018, 65).

\subsection{Previous Studies}

Al-Sani (2017) aimed to investigate the impact of strategic agility determinants in achieving organizational effectiveness dimensions. The study used a questionnaire that included (47) statements divided on 7 levels. The study sample consisted of 63 subjects and concluded that there was a significant effect of strategic in achieving organizational effectiveness. Al-Tamimi and Abdul-Ghafour (2017) aimed to pay attention to organizational factors related to building the right strategies that lead to achieving high levels of organizational effectiveness, as well as recognizing the reality of applying agility. The strategy impacts on effectiveness of banking sector. The study used the questionnaire to collect data and information. The study concluded that the Central Bank of Iraq had used strategic agility methods. Abdul Rahim and Fadel (2016) study aimed to find out strategic agility dimensions that interact with each other for the aim of forming intellectual frame strategic agility. The strategic agility dimensions are: Clarity of vision, Selected Strategic Targets, Core capacities, Shared responsibility, Taking action, Empowerment, Organic Structure, Planning Strategy, Organizational learning, Information technology, and Human recourse management. The study used a structured questionnaire for data collection and found that Asiacell company did not qualify to be called "agile organization" despite the fact that it has the characteristic of agile organizations. Hanieh (2016) aimed to identify strategic agility practicing the relationship with institutional performance excellence in food industries sector in Gaza Strip. The study used strategic agility determinants including Strategic sensitivity, clarity of vision, core capabilities, and strategic goals selection shared responsibility and speed response. The research concluded that strategic agility practicing and excellence in institutional performance mean in food industry companies was high for both people. The study also concluded strong statistically significant relationship between strategic agility practice of and performance excellence in food industries sector institutions in Gaza Strip. Shin et al. (2015) study aimed to find out agility nature, role and its influence on firm performance. The study concluded that strategic intent toward agility has an impact on operational performance and customer retention. Samir (2013) study aimed to find out the impact of strategic agility on operations competitive capabilities in Jordanian private hospitals. The study also aimed to find out the impact of strategic agility including clarity of vision, understanding core capabilities, selected strategic targets, shared responsibility, taking action on operation competitive capabilities: innovation, service quality, delivery reliability, process flexibility and cost leadership. The research used a questionnaire to collect 
the required data and concluded that there was a significant impact of some strategic agility dimensions on operations competitive capability in Jordanian Private Hospitals. Hasan (2019) aimed to identify strategic agility role in achieving organizational excellence. To achieve the research objectives, two main hypotheses were formulated and the research sample was selected in a random stratified consisting of (56) staff members. The research used the questionnaire to collect the required data and concluded that Strategic Agility and organizational excellence levels were high. The research also concluded that there was a correlation between strategic agility and organizational excellence. Ofoegbu and Ayobmi (2012) aimed to find out how strategic agility affects perceived performance of Nigerian manufacturing firms. The study investigated the potential positive influence of strategic agility on manufacturing. The study concluded that there is a positive relationship of strategic sensitivity, collective commitment, and resource fluidity to perceived organizational performance.

\section{Research Problem}

Commercial banks operating in Jordan are facing very accelerating environmental conditions and continuous change resulting from rapid change in their external environment, which requires that these commercial banks to take advantage of environmental surveys conducted to obtain valuable information to achieve their long-term goals. In addition, these commercial banks must also make strategic changes, in order to achieve growth, prosperity and the ability to run operations efficiently and creatively. Therefore, strategic agility is the strategic key associated with the current era to ensure the continuity of these organizations. The study importance stems in addressing an important topic (Strategy Agility) that has an impact on organizations. Strategic agility is a management activity practiced by organizations to improve their performance. Accordingly, the study will provide those in charge in Jordanian commercial banks with proposals to develop employee's performance through the use of strategic agility, which in its contributes help improve the productivity of these commercial banks and improve the quality of their banking services. The purpose of this research is to find out the impact of strategic agility, which includes strategic sensitivity, clarity of vision, core capabilities, strategic goals selection, shared responsibility, and information technology on employee performance in Jordanian commercial banks.

\section{Research Hypothesis}

$\mathbf{H}_{01}$ : There is no impact of strategic sensitivity on employee's performance in Jordanian commercial banks.

$\mathbf{H}_{02}$ : There is no impact of clarity of vision on employee's performance in Jordanian commercial banks.

Ho3: There is no impact of core capabilities on employee's performance in Jordanian commercial banks.

$\mathbf{H}_{04}$ : There is no impact of strategic goals selection on employee's performance in Jordanian commercial banks.

H05: There is no impact of shared responsibility on employee's performance in Jordanian commercial banks.

Ho6: There is no impact of information technology on employee's performance in Jordanian commercial banks.

\section{Research Methodology}

The researcher used some descriptive analytical method since such method describes the phenomenon under process, analyzing research data, and finding out the relationship between research variables.

\subsection{Population and Sample}

The study population consisted of all managerial positions in commercial banks in Jordan. A random sample of (270) managerial jobs were selected and the questionnaire was distributed, 20 questionnaires were disregarded due to incompetence, leaving us with 250 questionnaires which represents a response rate of $92.6 \%$

\subsection{Sources of data collection.}

The researcher used two main sources of information. First, data were collected from various resources such as: books, journals, newspapers, periodicals, and the web net to collect the required secondary data. A self-administrated questionnaire was used to collect the primary data. The questionnaire was built based on the previous studies. The following statistical analysis was uses:

1- Descriptive statistics (means, and standard deviations) to describe the sample responses with regard to strategic agility, 2- Multiple regression analysis to test the research hypothesis.

\section{Results}

\subsection{Validity and Reliability}

Questionnaire has been introduced to a number of universities professors to verify the validity of the instrument. 
The research used Cronbach Alpha test to verify instrument's reliability. The obtained value was 0.966 for the whole questionnaire. All obtained values are more than $0.60 \%$ which means that all values represent the instrument reliability. The results of this test are shown in Table 1 below

Table 1

Instrument Reliability

\begin{tabular}{llllll}
\hline Variable & No. of items & $\begin{array}{l}\text { Coefficient } \\
\text { Alpha }\end{array}$ & Variable & No. of items & $\begin{array}{c}\text { Coefficient } \\
\text { Alpha }\end{array}$ \\
\hline Whole instrument & 36 & 96.6 & Strategic Goals Selection & 4 & 81.3 \\
Strategic Sensitivity & 4 & 78.4 & Shared Responsibilities & 5 & 82.6 \\
Core capabilities & 5 & 76.8 & Information Technology & 6 & 86.7 \\
Clarity of Vision & 4 & 81.6 & Employees Performance & 7 & 91.6 \\
\hline
\end{tabular}

Results of reliability test in Table 1 indicate that Cranach's Alpha ratio for all variables, whether independent or dependent, ranged between $(81.3$ - 96.6.). All of which are acceptable since they were greater than $60 \%$. The statistical analysis results for strategic agility dimensions in commercial banks in Jordan indicated high level of impact on employees' performance. Means values were 3.86 with Standard deviation equal to 0.66424 for strategic sensitivity, 3.77 with Standard deviation equal to 0.66216 for core capabilities, 3.82 with Standard deviation of 0.68180 for clarity of vision 3.86 with Standard deviation of 0.70135 ) for strategic goal selection, 3.68 with standard deviation 0.68044 ) for shared responsibility, 3.68 with standard deviation of 0.68044 and 3.88 with standard deviation of 0.6653 for information technology.

Table 2

Means and Standard deviation of Strategic Agility Dimensions

\begin{tabular}{|c|c|c|c|c|c|}
\hline $\mathrm{N}$ & Variable & Mean & Std. Deviation & Ranking & Level \\
\hline 1 & Strategic Sensitivity & 3.86 & 0.66424 & 2 & High \\
\hline 2 & Core capabilities & 3.77 & 0.66216 & 5 & High \\
\hline 3 & Clarity of Vision & 3.82 & 0.6818 & 4 & High \\
\hline 4 & Strategic Goals Selection & 3.86 & 0.70135 & 2 & High \\
\hline 5 & Shared Responsibilities & 3.68 & 0.68044 & 6 & High \\
\hline 6 & Information Technology & 3.88 & 0.66537 & 1 & High \\
\hline
\end{tabular}

\subsection{Hypothesis Testing}

\section{The main hypothesis}

Ho: There is no statistically significant impact strategic agility dimensions including strategic sensitivity, core capabilities, clarity of vision, strategic goals information technology selection, share responsibility, on employees' performance in commercial banks in Jordan. Multiple regression analysis was used to find out strategic agility dimensions on employee performance in Jordan, and Table 3 shows the test results.

Table 3

The results of the main hypotheses

\begin{tabular}{|c|c|c|c|c|c|c|}
\hline \multirow{2}{*}{\multicolumn{2}{|c|}{ Model }} & Unstandardized Coefficients & Coefficients & \multirow{2}{*}{$\begin{array}{c}\text { Standardized } \\
\text { Coefficients } \\
\text { Beta }\end{array}$} & \multirow[b]{2}{*}{$\mathrm{T}$} & \multirow[b]{2}{*}{ Sig. } \\
\hline & & $\mathrm{B}$ & Std. Error & & & \\
\hline 1 & (Constant) & -.324 & .146 & & -2.215 & .028 \\
\hline & Strategic Sensitivity & .020 & .051 & .018 & .394 & .694 \\
\hline & Core capabilities & -.129 & .061 & -.113 & -2.123 & .035 \\
\hline & Clarity of vision & .440 & .062 & .398 & 7.056 & .000 \\
\hline & Strategic goals selection & -.053 & .060 & -.049 & -.881 & .379 \\
\hline & Shared responsibilities & -.023 & .063 & -.020 & -.358 & .720 \\
\hline & Information Technology & .804 & .062 & .708 & 12.868 & .000 \\
\hline
\end{tabular}

Table 3 indicates that three independent variables (core capabilities, clarity of vision, strategic goals selection) have a statistically significant impact at $(\mathrm{a} \leq 0.05)$ level on employee performance in commercial banks in Jordan. The values of Beta $(\beta)$ verify these results, in addition to $\mathrm{T}$ calculated values.

The first Sub -hypothesis: There is no statistically significant impact of strategic sensitivity at ( $\alpha \leq 0.05)$ level on employee performance in commercial banks in Jordan

A simple regression for the effect of strategic sensitivity on employee performance yields a beta value of 0.614 . The estimated $\mathrm{R}$ value is equal to 0.614 , which indicates a fair relationship between the independent and independent variables. In addition, $\mathrm{R}^{2}$ value was 0.376 , which means that $37.6 \%$ of variance in employee performance is due to variance in strategic sensitivity. The calculated $t$ is equal to $12.236(\mathrm{Sig}=0.000)$, which means there is a statistically significant impact at $(\alpha \leq 0.05)$ level of strategic selectivity on employee performance in Jordanian commercial banks. 
Second Sub- Hypotheses: The second Sub-hypothesis: There is no statistically significant impact of core capabilities at ( $\alpha$ $\leq 0.05$ ) level on employee performance in commercial banks in Jordan

Again, the implementation of a simple regression to study the effect of core capabilities on employee performance yields a beta value of 0.655 . The estimated $\mathrm{R}$ value is equal to 0.655 , which shows a good relationship between the independent and independent variables. In addition, $\mathrm{R}^{2}$ value was 0.429 , which indicates that $42.9 \%$ of variance in employee performance was due to variance in core capabilities. The calculated $t$ is equal to $13.652(\mathrm{Sig}=0.000)$, which indicates that there was a statistically significant impact at $(\alpha \leq 0.05)$ level of core capabilities on employee performance in Jordanian commercial banks.

Third Sub- Hypotheses: The third Sub-hypothesis: There is no statistically significant impact of clarity of vision at ( $\alpha$ $\leq 0.05)$ level on employee performance in commercial banks in Jordan

One more time, the regression method between the relationship of clarity of vision and employee performance results a beta value of 0.753 . The estimated $\mathrm{R}$ value is equal to 0.753 , which denotes a relatively high relationship between the independent and independent variables. In addition, $\mathrm{R}^{2}$ value was 0.567 , which shows that $56.7 \%$ of the variance in employee performance was due to variance in clarity of vision. The calculated $t$ is equal to $18.005(\mathrm{Sig}=0.000)$, which indicates that there was a statistically significant impact at $(\alpha \leq 0.05)$ level of clarity of vision on employee performance in Jordanian commercial banks.

Fourth Sub-Hypotheses: The fourth Sub-hypothesis: There is no statistically significant impact of shared responsibility at $(\alpha \leq 0.05)$ level on employee performance in commercial banks in Jordan

For the fourth sub-hypothesis, the regression method implementation between shared responsibility and employee performance returns a beta value of 0.680 . The estimated $\mathrm{R}$ value is equal to 0.680 , which indicates a relatively high relationship between the independent and independent variables. In addition, $\mathrm{R}^{2}$ value was 0.462 , which means that $46.2 \%$ of the variance in employee performance was due to variance in shared responsibility. The calculated $t$ is equal to $14.596(\mathrm{Sig}=0.000)$, which indicates that there was a statistically significant impact at $(\alpha \leq 0.05)$ level of shared responsibility on employee performance in Jordanian commercial banks.

Fifth Sub- Hypotheses: The fifth Sub-hypothesis: There is no statistically significant impact of strategic goals selection at $(\alpha \leq 0.05)$ level on employee performance in commercial banks in Jordan

Again, the implementation of a simple regression to study the impact of strategic goals on employee performance provides a beta value of 0.736 . The estimated $\mathrm{R}$ value is equal to 0.736 , which demonstrates a good relationship between the independent and independent variables. In addition, $\mathrm{R}^{2}$ value was 0.542 , which indicates that $52.2 \%$ of variance in employee performance was due to variance in strategic goals. The calculated $t$ is equal to $17.130(\mathrm{Sig}=0.000)$, which means that there was a statistically significant impact at $(\alpha \leq 0.05)$ level of core capabilities on employee performance in Jordanian commercial banks.

Sixth Sub- Hypotheses: The first Sub-hypothesis: There is no statistically significant impact of technology at ( $\alpha \leq 0.05)$ level on employee performance in commercial banks in Jordan

Finally, the implementation of a simple regression to study the impact of technology on employee performance yields a beta value of 0.860 . The estimated $\mathrm{R}$ value is equal to 0.860 , which demonstrates a high relationship between the independent and independent variables. In addition, $\mathrm{R}^{2}$ value was 0.739 , which indicates that $73.9 \%$ of variance in employee performance was due to variance in technology. The calculated $t$ is equal to $24.494(\mathrm{Sig}=0.000)$, which means that there was a statistically significant impact at $(\alpha \leq 0.05)$ level of technology on employee performance in Jordanian commercial banks.

\section{Conclusions and Recommendations}

Based on the analytical analysis the study concludes that strategic agility has an impact on employee's performance in commercial banks in Jordan. The research also concluded that strategic agility dimensions including strategic sensitivity, core capabilities, clarity of vision, strategic goals information technology selection, and share responsibility, have some positive impacts on employee's performance in commercial banks in Jordan. The study recommends that commercial banks in Jordan adopt the strategic agility approach to improve their employee's performance. The commercial banks must exert their best efforts to rapidly adapt to the surrounding environmental variables. Commercial banks have to pay attention to human capital, which has a major role in achieving good performance. Moreover, Commercial banks have to support and encourage creativity and innovation processes, through testing innovative ideas and solutions provided by employees' involvement.

\section{References}

Abdul Rahim, S., \& Fadel, O. (2016). Strategic agility dimensions and adapted in business organizations/field research analytical in Asia cell mobile telecommunications. Journal of Economics And Administrative Sciences, 22(94), 112-137

Al-Tameemi, A. H., \& Abd-Alghafur, Q. A. (2020). The effect of strategic agility on organizational effectiveness Applied research at the Central Bank of Iraq. Tikrit Journal of Administration and Economics Sciences, 16(50), 322-341 
Al-Abdi, A. (2012), Organizational agility: A strategic approach to the enhancement process occupation for employees (a pilot study of a sample of the industrial sector companies in a ministry Industry and Minerals), Al-Gharry Journal of Economic Sciences, 24(1), 166-189.

Al-Badrani, I. A., (2015), the relationship of administrative empowerment with work teams and its impact on the investigation of Strategic Agility, a field study on a number of hospitals in Erbil Governorate, Journal of Unbar University for Economic and Financial Sciences, 2(1), 79-92.

Al-Maadidi, M. (2016). Information technology capabilities and their impact on the strategy agility, a case studies in the State Company for Medicines and Medical Appliances in Nineveh Iraqi Journal of Administrative Sciences, 3(1), $221-238$.

Al-Sani, I. S. (2017) The Impact of Strategic Agility Determinants in Organizational Effectiveness (Case study of Lafarge Co. Jordan Cement, MSC, Unpublished MA thesis, Middle East University, Jordan.

Al-Sharif, R. B. E. (2015). The effect of strategic flexibility on the relationship between learning the strategy and achieving competitive advantage in the Jordanian insurance companies. Unpublished MA thesis, Middle East University, Jordan.

Al-Zaben, N. (2012). The effect of strategic information characteristics on achieving agility Strategy and the Role of Competitiveness as a Modifying Variable: An Empirical Study on Alba House in Jordan, Unpublished MA thesis, Middle East University, Jordan.

Chow, I. T., \& Chew, I. (2013). HRM systems and firm performance: The mediation role of strategic orientation. Asia Pacific Journal of Management, 30(1), 53-72.

Guan, X. \& Frank, S. (2018). How perceptions of training impact employee performance: Evidence from two Chinese manufacturing firms. Personnel Review, 48(2), 163-183.

Hanieh, M. (2016). Practicing Strategic Agility and Its Relationship to Institutional Performance Excellence in the Food Industry Sector in Gaza Strip MSC, Islamic University, Gaza.

Hasan, W. N. (2019). The role of strategic Agility in organizational excellence In Ministry of Construction, Housing, Municipalities and Public Works. Journal of Economics and Administrative Sciences, 15(1), 110-132.

Liu,Y. (2010). Implementing Sustainable Competitive Advantage for Proactive Operations in Global Turbulent Business Environments. Dissertation Submitted in partial fulfillment of the requirements for the degree of doctoral in industrial management. University of Vaasa. Finland.

Dehaghi, A. K., \& Navabakhsh, M. (2014). Study the effect of organizational factors to implementing the agility strategy in Isfahan Municipality. International Journal of Academic Research in Business and Social Sciences, 4(1), 315-326.

Khoshnood, N. T., \& Nematizadeh, S. (2017). Strategic agility and its impact on the competitive capabilities in Iranian private banks. International Journal of Business and Management, 12(2), 220-229.

Ofoegbu, O. E., \& Akanbi, P. A. (2012). The influence of strategic agility on the perceived performance of manufacturing firms in Nigeria. International Business \& Economics Research Journal (IBER), 11(2), 153-160.

Pawirosumarto, S., Sarjana, P. K., \& Gunawan, R. (2017). The effect of work environment, leadership style, and organizational culture towards job satisfaction and its implication towards employee performance in Parador Hotels and Resorts, Indonesia. International Journal of Law and Management. 59(6), 1337-1358.

Sajdak, M. (2015). Compilation of operational and strategic agility for ensuring the highest efficiency of company operations. Ekonomia i Zarzadzanie, 7(2), 20-25.

Samir, A. S. (2013) Strategic Agility and Its Impact on the Operations Competitive Capabilities in Jordanian Private Hospitals, Unpublished MA thesis, Middle East University, Jordan.

Santala, M. (2009). Strategic Agility in a small Knowledge Intensive Business Services Company: Case Swot Consulting. Department of Marketing and Management, Master Thesis, Helsinki School of Economics, Aalto University.

Shin, H., Lee, J. N., Kim, D., \& Rhim, H. (2015). Strategic agility of Korean small and medium enterprises and its influence on operational and firm performance. International Journal of Production Economics, 168, 181-196.

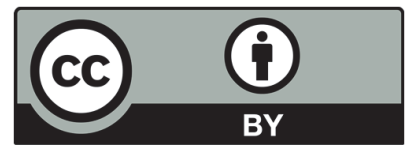

(C) 2021 by the authors; licensee Growing Science, Canada. This is an open access article distributed under the terms and conditions of the Creative Commons Attribution (CC-BY) license (http://creativecommons.org/licenses/by/4.0/). 